Keskin, F.; Ömeroğlu, E. ve Okur, A. (2015). 0-6 Yaş Arasındaki Çocuklara Sözcük Öğretimi ile ilgili Çalışmaların İncelenmesi 3(1), 80-95.

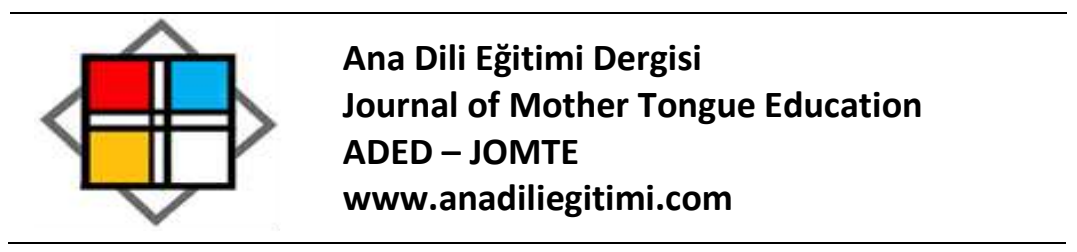

\title{
0-6 Yaş Arasındaki Çocuklara Sözcük Öğretimi İle ilgili Çalışmaların İncelenmesi
}

\author{
Funda KESKIN* \\ Engin Ömeroğlu** \\ Alparslan OKUR ${ }^{* * *}$ \\ Özet
}

\begin{abstract}
Çocuğun dili kullanmayı öğrenmesi, çocuk gelişiminin en önemli göstergelerindendir. Bu gelişimin doğum öncesinden başladığı düşünülerek çocuğun, dil ile ilgili becerileri bu andan itibaren öğrendiği kabul edilmektedir. Çocuğun biyolojik kapasitesiyle birlikte çevrenin ve eğitimin dil gelişimi üzerinde etkisi büyüktür. Bu nedenle çocuğun ana dilini kazanırken geçirdiği aşamalarda eğitimin destekleyici rolünden yararlanılmalıdır. Bu doğrultuda ilköğretime başlayana kadar olan 06 yaş döneminde yapılan dil gelişimine yönelik çalışmalar önemlidir.

Tarama modelinin kullanıldığı ve doküman incelemesi yapılarak verilerin toplandığı bu araştırmanın çalışma grubunu 0-6 yaş arasındaki çocuklara sözcük öğretimiyle ilgili çalışmalar oluşturmaktadır. Çalışmada 0-6 yaş arasındaki çocuklara sözcük öğretimiyle ilgili olarak tespit edilen toplam 40 çalışma üç alt başıkta incelenmiş, kelime hazinesine yönelik 11 çalışma; uygulamanın esas olduğu 19 çalışma; teorik bilgi veren 9 çalışma tespit edilmiştir. Çalışmanın sonucunda tespit edilen çalışmaların benzer ve farklı özellikleri belirlenmiş ve çalışmalarda yoğun olarak işlenen başıklar saptanmış ve değerlendirilmiştir.
\end{abstract}

Anahtar Kelimeler: Sözcük öğretimi, sözcük edinimi, dil edinimi, söz varlığı.

\section{An Investigation of the Studies about Vocabulary Teaching To Children between 0-6}

Ages

\begin{abstract}
The children's learning how to use language is essential part of children's development. It is accepted that this development starts before children's birth and also these skills which are related with language is learnt since the moment. Apart from the children's biological capacity, both environment and also education effects well on language development. For this reason, the supportive role of education should be used during the period that a child acquires his/her mother tongue. The study group of this research during which screening model is used and document review is done includes studies related to vocabulary teaching to the children. Consequently, total 40 studies which are about to vocabulary teaching to children whore are between $0-6$ age are examined under three titles. It is found that 11 studies which are about vocabulary capacity, 19 studies which are about mostly related with practice, 9 studies which gives theoretical information.
\end{abstract}

Keywords: Vocabulary teaching, vocabulary acquisition, language acquisition, word wealth

\footnotetext{
* Doktora Öğrencisi, Sakarya Üniversitesi, Eğitim Fakültesi, Türkçe Eğitimi Bölümü. Sakarya. e-posta: funda yamac@yahoo.com

${ }^{* *}$ Okt. Engin Ömeroğlu, Sakarya Üniversitesi Türk Dili Bölümü, omeroglu@sakarya.edu.tr

${ }^{* * *}$ Doç. Dr., Sakarya Üniversitesi, Eğitim Fakültesi, Türkçe Eğitimi Bölümü, Sakarya.

e-posta: aokur@sakarya.edu.tr
} 
0-6 Yaş Arasındaki Çocuklara Sözcük Öğretimi ile ilgili Çalışmaların İncelenmesi

\section{Giriş}

İnsan bütün yaşamı boyunca okuma yazma bilmeden yaşayabilir; fakat dili edinmeyip konuşmayı öğrenmeden yaşayamaz. Dil öğrenimi bebeklik sırasında gerçekleştiği için, dil öğrenim işlemini sistemli bir şekilde izleme olanağı her zaman mümkün değildir. Dil edinim sürecini anlamak için değişik gözlemler ve araştırmalar yapılmış, bunların sonucunda değişik teoriler ortaya atılmıştır fakat bu süreci çözmek mümkün olamamıştır. Fromkin ve Rodman (1978 : 243) bu alanda bilinen genellemeleri şöyle sıralamışlardır:

1. Çocuklar dildeki tüm sözcükleri ve tümceleri belleklerinde depolayarak öğrenmezler.

2. Çocuklar, çoğunu daha önce hiç duymadıkları tümceler kurmayı öğrenirler.

3. Çocuklar daha önce hiç duymadıkları tümceleri işittiklerinde anlamayı öğrenirler.

4. Bu nedenle, çocuklar, dili yaratıcı bir biçimde kullanmaya yardımcı olacak "kuralları" öğrenirler.

5. Bu kuralları onlara kimse öğretmemektedir. Onların dil öğrenme süreçlerinde ana babaları da bu yönde yardımcı olamamaktadır; zira onlar da çocukları ile konuşurken dilbilim kurallarını akıllarına bile getirmemektedirler. O halde, çocuklar gerçek dil teorileri ile donanmıs iyi bir dilbilimci gibi davranmakta ve duydukları dilin gramerini ortaya koymak için de sahip oldukları bu dil teorisinden yararlanmaktadırlar (Akt. Ekmekçi, 1979).

Çocukların dil gelişimleri incelendiğinde, bebekler daha birkaç haftadan itibaren sesli uyarıları algılamaya ve onlara tepkide bulunmaya başlarlar. Üçüncü aydan itibaren, annelerinin sesini, başka bir insanın sesinden ayırabilirler. 12-15 aylıkken ilk sözcüklerini söylerler. Çocuk ihtiyacı olan iletişimi bu evrede mimiklerle, ağlama biçimleriyle ve anlamsız mırıldanmalarla karşılar. 15 aylık bir bebek, daha çok işaret amaçlı dil kullanımını tercih eder. Konuşma sırasındaki kelimeleri veya işittiklerini kullanabilir. 18 aylık bir bebek yaklaşık olarak 20-30 kapasitelik kelime hazinesine sahiptir. Yetişkinlerle soru-cevap şeklinde iletişim kurmaya çalışır. 21 aylık bir çocuk bazı zamirleri anlar ve benim, senin, ben ve sen kelimelerini çok kullanır. 24 aylık çocuğun söz dağarcığında yaklaşık 200-300 kelime vardır. Kısa ve tam olmayan cümleler kurar. Üç yaşındaki çocuklar artık kelimelerle oynayabilir, 900-1000'e varan bir kelime hazinesine sahiptirler. 4 yaşında ise yaklaşık 1500-2000 kelime dağarcığıyla oldukça çok soru sorarlar, daha karmaşık cümle yapılarını kullanırlar. Çocuklar gramer kurallarının \%90'ını 5-6 yaşlarında tamamlarlar. Duygularını ifade etmeye başlarlar ve 2-3 bin konuşma, 20-24 bin anlama kelime hazinesine sahiptirler (Dağabakan ve Dağabakan Ö., 2007: 6).

0-6 yaş arası çocuklara sözcük öğretimi, eğitim ve öğretimle ilgilidir. Keklik’e göre (2011:6) Çocuğun dil ve kelime hazinesinin gelişimi konusunda anne babanın bilinçli olması gerekmektedir. Anne baba çocuğuyla nitelikli ve çeşitli oyunlarla, etkinliklerle vakit geçirmelidir. Resimli hikâye kitapları, boyama kitapları, parmak oyunları gibi çeşitli etkinliklerle çocuğun dil ve kelime hazinesi gelişimine yardımcı olmalıdır. 
Okul öncesi eğitimin de 0-6 yaşa arasındaki çocukların sözcük hazinelerinin gelişimine önemli etkileri bulunmaktadır. Bu eğitimi veren kurumların günlük program uygulamaları içerisinde yer verilen etkinliklerin önemli biri bölümünü dil etkinlikleri oluşturmaktadır. Bu etkinlikler çocukların yeni sözcükler öğrenerek sözcük dağarcıklarını geliştirmelerine, sözcükleri doğru ve yerinde kullanabilmelerine, dil aracılığıyla düşüncelerini ifade edebilmelerine ve kitap sevgisi ve kitap okuma alışkanlığı kazanabilmelerine yardımcı olmaktadır (Zembat ve Yurtsever, 2002). Yapılan bu çalışmada 0-6 yaş arası çocuklara sözcük öğretimiyle ilgili çalışmaların benzer ve farklı özelliklerin belirlenmesi, çalışmaların Türkçe dersi için sözcük öğretimine katkılarının incelenmesi ve çalışmalarda yoğun olarak işlenen başlıkları saptanması hedeflenmiştir.

\section{Yöntem}

Nicel ve nitel veriler sunması bakımından karma araştırma özelliği taşıyan çalışma tarama modeliyle gerçekleştirilmiştir. Tarama modelinde geçmişte ya da halen var olan durumu olduğu gibi betimlemek amaçlanmaktadır. Onları değiştirmek gibi bir amaç yoktur ve önemli olan onu iyi bir şekilde gözleyip belirlemektir (Karasar, 2010: 77). Bu amaç doğrultusunda yapılan çalışmalar incelenmiştir.

\section{Araştırmanın Evren ve Örneklemi}

Araştırmada taranan çalışmanın kapsamı YÖK'te erişime açık bulunan tezler ve ULAKBiM'de taranan makaleler ve basımına ulaşılabilen kitaplar ile sınırlandırıımıştır. Araştırmanın evrenini 0-6 yaş arası çocuklara sözcük öğretimi ile ilgili çalışmalar, örneklemini ise araştırmacılar tarafından evrenin ulaşılabilen kısmı oluşturmaktadır. Örneklem olarak kabul edilen 41 çalışmanın; 20 tanesi tez (14 tanesi yüksek lisans ve 6 tanesi doktora tezi), 16 tanesi makale ve 4 tanesi kitaptır.

\section{Verilerin toplanması}

Verilerin analizini yapmak amacıyla öncelikle 0-6 yaş arasındaki çocuklara sözcük öğretimi ile ilgili yapılan çalışmaların taranması için "Ulusal Akademik Ağ ve Bilgi Merkezi", "Asos İndex", "Çukurova Üniversitesi-Makale Bilgi Sistemi" ve "Google Scholar"da taranan araştırmalar ve yazılı kaynaklar veri toplama aracı olarak kullanılmıştır.

\section{Verilerin Analizi}

Verilerin analizini yapmak amacıyla öncelikle 0-6 yaş arasındaki çocuklara sözcük öğretimi ile ilgili yapılan çalışmalar taranmış, detaylı bir şekilde incelenmiş, ardından yapılan çalışmaların benzerlikleri ve farklılıkları "kelime hazinesine yönelik çalışmalar, uygulamanın esas olduğu çalışmalar, teorik bilgi veren çalışmalar" başlıkları altında incelenmiştir. 
0-6 Yaş Arasındaki Çocuklara Sözcük Öğretimi ile ilgili Çalışmaların İncelenmesi

\section{Bulgular}

Araştırmada incelenen çalışmalar, çalışmalarda aktarılan bilgilere göre kelime hazinesine yönelik çalışmalar, uygulamanın esas olduğu çalışmalar ve teorik bilgi veren çalışmalar olmak üzere üç ana başlıkta incelenmiştir.

\section{Kelime Hazinesine Yönelik Çalışmalar}

Konuşmayı ve diğer insanları anlamayı öğrenmek, çocukların geliştirdiği en karmaşık yeteneklerindedir. Dili kullanmanın bir amaca yönelik işlevi vardır. Dilin işlevi; insanın neden konuştuğu ile ilgili öğrenme, isteme gibi amaçlarla ilgilidir. Çocukların; duygularını, düşüncelerini, ilgilerini, isteklerini ifade etmek için iletişime girmeleri gerekir. Iletişim; başkalarının söylediklerini anlamalarını, sözcük dağarcığı geliştirmelerini, sözcükleri doğru olarak telaffuz etmelerini ve anlaşılır bir cümle yapısını kavramalarını sağlar. 0-6 yaş arasındaki çocukların kendilerini sözlü olarak ifade etmeleri onların dillerini ne kadar aktif olarak kullandıklarını ve sözcük dağarcıklarının ne kadar zengin olduğunu göstermelerindeki en önemli ölçüttür. Sözcük öğretiminin konuşma becerisindeki durumunu tespit etmek ve çözüm önerileri sunmak amacıyla çeşitli çalışmalar yapılmıştır. Bu çalışmalar 0-6 yaş döneminde dil gelişimi aşamalı olarak geliştiğinden genellikle çocukların belirli yaş aralıklarına göre ele alınmıştır.

1-2 yaş arasındaki bir çocuk sözcükleri birleştirme yeteneğine sahiptir. Çocuklar sözcüklerin birbirleriyle olan ilişkilerini kavramaya başlar. Çocukların bu dönemde kullandığı sözcüklerin çoğunu isimler oluşturmaktadır. Artar(1998)'da Ankara'da yaşayan 9-26 aylık bebeklerin dil normları aile bilgisine dayalı olarak saptanmıştır. Yapılan araştırmanın sonucunda araştırmanın bulguları aşağıdaki şekilde özetlenebilir: a. Edinimin ilk aylarında, sözcüklerin niteliği aşağıdaki gibi sıralanabilir: Aile üyesi: Baba, dede, anne, hala. Eylem: Gel, ver, git. Hayvan:Hav hav, miyav. Yiyecek: Mama, muz, elma. Nesne:Saat, top, bebek. b. Her ayda edinilen sözcük sayılarında gelişimsel bir ilerleme olduğu görülmektedir. 25. ve 26. aylar arasında bir farklılık bulunmamıştır. c. Her ayda edinilen sözcük sayılarında cinsiyete bağlı bir değişim görülmemektedir. d. Her ayda edinilen sözcük sayılarında sosyoekonomik düzeye bağlı bir değişim görülmemektedir. e. Her ayda edinilen sözcüklerin türlerinde gelişimsel bir ilerleme olduğu görülmektedir. f. Her ayda edinilen sözcüklerin türlerinde cinsiyete bağlı bir değişim görülmemektedir. g. Her ayda edinilen sözcüklerin türlerinde sosyo-ekonomik düzeye bağlı bir değişim görülmemektedir.

2-3 yaş arası dönem çocuktan çocuğa dil gelişimi ve dilin kullanılması açısından büyük farkların gözlemlendiği dönemdir. Bu dönemde dil hataları sıklıkla görülmektedir ve çocuklar tek cümle ile anlatabilecekleri bir işi iki cümle ile anlatmaktadırlar. Büyüklük, küçüklük, öncelik sonralık, azlık, çokluk 
ve zıtlık durumlarını karşılaştırmak ve kavramakta güçlük çekerler. 3-4 yaş arası dönemde ise çocuklarda ben merkezli konuşmaların yoğun olarak görülmektedir.

Acarlar (1991) orta sosyoekonomik düzeydeki ailelerin 30-47 aylar arasındaki anaokuluna devam eden çocuklarının kullandıkları cümlelerdeki dil yapısını incelemiştir. Bütün çocuklar altı ay boyunca her ay bir saat izlenmiş ve çocuklara bu gözlem sürecince altı etkinlik programı uygulanmıştır. Ailelerin ve araştırmacının belirlediği etkinlikler çerçevesinde uyguladıkları çalışmalar ayda üç kez yirmişer dakika olmak üzere kayıtları alınmıştır. Altı ay süresince otuz çocuktan toplam 9. 000 cümle alınmıştır. Verilerin değerlendirilmesinde ki-kare ve fisher ki-kare testi kullanılmıştır. Bu cümleler kelime sayısı, kelime çeşitleri, isim durumları, adların iyelik ve çoğul ekleri, fiil kipleri, fiilimsiler özne çeşitleri ve cümle çeşitleri yönünden analiz edilmiştir. Cümlelerdeki kelime sıklığı cinsiyete ve yaşa göre gruplar arasındaki fark önemli bulunmuştur. Kelime türlerini kullanma sıklığı yaş ve cinsiyete göre gruplar arasındaki fark önemli bulunmuştur. Bütün yaş gruplarında en sık fiilleri kullandığı Yüksel (2003) 30- 47 aylar arasındaki çocukların cinsiyeti, yaşı ve annenin eğitim durumuna bağıı olarak dil yapılarının anlamsal yönden nasıl değiştiğini belirlemiştir. Çalışma sonucunda çocukların dil yapılarını anlamaları ve sözcük dağarcıklarında cinsiyet etkisi anlamlı bulunmazken, yaş etkisi anlamlı bulunmuştur. Buna karşılık annenin eğitim durumunun çocukların dil yapılarım etkilediği fakat sözcük dağarcıklarım etkilemediği bulgusu ortaya konmuştur.

4-5 yaş aralığı çocukların konuşma becerilerinde belirgin bir düzelmenin görüldüğü dönemdir. Bu dönemde çocuklar tekerleme türü ifadelere aşırı ilgi göstermektedir. Çocuklar konuşma dilinin yanında yazı diline de ilgi duymaya başlamıştır. 5-6 yaş arasında ise çocuklar ben merkezli dil kullanımından yavaş yavaş kurtulmaya başlar. Taklit yerini öğrenme amaçlı sorulara bırakır. Merak kaynaklı sebep sonuç ilişkilerini kavramaya yönelik sorular bu dönemde baş gösterir. Kelime hazinesine yönelik çalışmalara bakıldığında çalışmaların genellikle 4-6 yaş aralığındaki çocuklar üzerinde yapıldığı görülmektedir. Çalışmalarda çocuklardaki kelime hazinesinin sosyoekonomik düzeye, yaş aralığına, cinsiyete göre değişip değişmediği araştırılmıştır.

Erkan (1990) sosyoekonomik ve eğitim düşeyi düşük olan ailelerin 4-5 yaşlarındaki çocukları ile sosyoekonomik ve eğitim düzeyi yüksek olan ailelerin 4-5 yaşlarındaki çocuklarının kullandıkları cümleleri dil yapısı yönünden incelemiştir. Çalışma sonunda sosyoekonomik düzeyi yüksek olan ailelerin çocuklarının dil düzeylerinin sosyoekonomik düzeyi düşük olan çocuklara göre daha yüksek çıkmıştır.

Dereli (2003) okul öncesi eğitime devam eden 4-6 yaşlar arasındaki çocukların ifade edici dil düzeylerinin özlük nitelikleri (yaş, cinsiyet, sosyo-kültürel özellikler) ve bakım tarzına göre farklılaşıp farklılaşmadığı incelemiştir. Araştırmadan elde edilen bulgular şu şekilde özetlenebilir: 1 . Anaokuluna 


\section{0-6 Yaş Arasındaki Çocuklara Sözcük Öğretimi ile ilgili Çalışmaların İncelenmesi}

devam eden çocukların yaşlarına göre dil gelişimi düzeyleri arasında önemli bir fark olduğu bulunmuştur. 2. Anasınıfına devam eden çocukların yaş, anne eğitimi ve sosyo-ekonomik düzeylerine göre dil gelişimi düzeyleri arasında önemli bir fark olduğu bulunmuştur 3. Anasınıfına devam eden çocukların cinsiyet ve baba eğitim durumunu dil gelişimi düzeyleri arasında önemli bir fark oluşturmadığı bulunmuştur. Araştırma sonuçlan doğrultusunda eğitimci ve ebeveynlere dil gelişimi destekleyici ve zenginleştirici öneriler sunulmuştur.

Gökmen (2007)'de 4-6 yaş arasındaki çocukların doğal konuşma bağlamları incelenmiştir. Geç dönem içinde bulunan ve Türkçeyi edinen çocukların kullanımlarında da ad baskınlığının olup olmadığı konusu ele alınmıştır. Çalışmada ulaşılan en önemli sonuç, üç yaş grubu için de geçerli olmak üzere ad ulamından çok eylemlerin kullanımında bir baskınlık olduğu yönündedir. Ayrıca, çocukların en yoğun olarak kullandıkları eylem türü de olaydır.

Yıldırım vd. (2010) alt sosyo-kültürel düzeyde normal gelişim gösteren ve zihin engelli çocukların sözcük dağarcığı düzeyleri belirlenmeye çalışılmıştır. Araştırmanın sonucunda alt sosyokültürel düzeydeki normal çocukların ve engelli çocukların cinsiyetlerine göre sözcük dağarcığı arasında anlamlı bir fark bulunmamıştır.

Ekmekçi (1979) anadili öğreniminde evrensel olarak tanımlanan etkenlerin Türkçe öğrenimindeki uygunluğunu saptama amacı ile bir Türk çocuğunun nasıl bir dil gelişimi gösterdiğini araştırmıştır. Araştırma sonucuna göre anadili öğreniminde çocuğu dil gelişimi dilin özne, nesne, eylem veya özne, eylem, nesne yapısında olup olmamasına göre değişiklik göstermektedir. Çocuğun anadilini öğrenmesi yönünden, ÖEN dizisinde (İngilizce) sözcüklerin sıralanması dil ve anlam yönünden açıklık getirdiğinden kullanılan çekim eklerinin anlama katkısı yoktur. ÖNE dizisinde (Türkçe) ise takılar yapı ve anlam ilişkilerini yüklendikleri için çocuk önce takılarla sözcükler arasındaki ilişkileri öğrenme zorunluluğunu duymaktadır.

Güleryüz (1990) orta sosyoekonomik düzeydeki çalışan ailelerin 48-60 aylar arasındaki anaokuluna devam eden çocukların kullandıkları cümleleri dil yapısı yönünden incelemiştir. Çalışma sonucunda çocukların kullandıkları dil öğelerinin kullanım sıklıkları belirtilmiştir. Çalışmada 48-60 aylar arasındaki anaokuluna devam eden çocuklarının çocukların kullandıkları cümlelerdeki sözcük sayısı incelendiğinde; en yüksek olarak üç sözcüklü cümlelerin, daha sonra sırasıyla dört sözcüklü, iki sözcüklü, beş sözcüklü, altı sözcüklü, sekizden fazla sözcüklü ve sekiz sözcüklü cümleleri kulandıkları görülmüştür. Sözcük çeşitlerinden isimlerin, daha sonra fil, zamir, zarf, bağlaç, sıfat, edat ve ünlemlerin kullanıldığı bulunmuştur.

Savaş ve Turan (2011) okul öncesinde öğrenim gören 6 yaş grubu öğrencilerin sahip oldukları kelime servetini çeşitli değişkenler açısından değerlendirmişlerdir. Araştırma sonucunda araştırmaya 
katılan 30 okul öncesi öğrencinin araştırma süresince toplam 49677 harf-ses kullandıkları tespit edilmiştir. Araştırma sürecinde öğrenciler en fazla $A, E, R, I, N$ ve $M$ seslerini, en az J, F, Ö, C, P seslerini kullanmışlardır. Öğrenciler en fazla 'ben' kelimesini tekrar etmişlerdir. Yine sık kullandıkları kelimeler arasında 'orada, bir, çok, var, sevmek, anne, olmak, baba, biz' kelimeleri yer almaktadır. Araştırmaya katılan öğrencilerin kullandıkları kelimelerde başlangıç harfine göre sahip oldukları kelime servetlerine göre öğrencilerin en fazla 'A ve E' sesi ile başlayan kelimeleri kullanıldıkları görülmüştür. Öğrencilerin en az 'J ve I' sesi ile başlayan kelimeleri az kullandıkları tespit edilmiştir. Öğrencilerin sahip oldukları kelime servetlerinde aile eğitim durumunun önemli bir faktör olduğu da tespit edilmiştir. Anne ve baba eğitim düzeyi yüksek olan öğrencilerin kelime servetinin daha fazla olduğu tespit edilmiştir.

Aktürk (2012) 8-36 aylık çocukların sözcük dağarcı̆̆ı, dilbilgisi ve iletişim davranışları hakkında annelerden toplanan veriler ile çocukların konuşma örnekleminden toplanan verilerin arasındaki ilişkiyi karşılaştırmıştır. Araştırma sonunda farklı eğitim düzeyinden annelerin, eğitim seviyelerinden bağımsız olarak, 8-36 ay yaş dilimindeki çocuklarının dil ve iletişim becerileri üzerine verdikleri bilgilerin, çocuktan toplanan veriyle tutarlılığı saptanmıştır.

Çocuk gelişimi ve eğitiminde, erken çocukluk eğitimi ve özel eğitim önemli bir yer tutar. Çocuğu ve gelişimini bilmek, insanı tanımak olarak nitelendirilebilir. Yaşamın ilk yıllarında başlayan gelişim, çocuğun ileriki yaşlardaki yaşantısını büyük ölçüde etkileyecek bir süreçtir. Illk yıllar, çocuk gelişiminin hızlı olduğu kritik yıllardır. Bu erken gelişim yıllarında, temeli atılan gelişimlerden biri de dil gelişimidir. Bu nedenle çocuğun dil gelişimini takip etmek çocuğun ileri dönemlerdeki gelişimini görebilmek açısından birçok ipucu verecektir. Çalışmada tespit edilen 0-6 yaş arasındaki çocukların kelime hazinesine yönelik çalışmalarda elde edilen bulgular genellikle şu şekildedir:

- Çocukların kullandıkları dil yapıları incelenmiş ve en çok kullandıkları kelimeler sıklık çalışmaları ile betimlenmiştir.

- Çocukların dil gelişimlerinde her ay ilerleme olduğu gözlemlenmiştir.

- Anaokuluna giden çocukların kelime servetinin anaokuluna gitmeyen çocukların kelime servetine göre daha yüksek olduğu saptanmıştır.

- Annenin kullandığı dil yapılarının çocukların dil yapılarını etkilerken sözcük dağarcığını etkilemediği ortaya çıkmıştır.

- Çocukların sözcük dağarcıklarında Türkçenin dil yapısından dolayı isimlerden çok eylemlerin olduğu ortaya çıkmıştır.

\section{Uygulamanın Esas Olduğu Çalışmalar}

Eğitim-öğretim sürecinde teorik bilgileri öğretmek ne kadar önemliyse onların uygulanması da aynı derecede önemlidir. Uygulama sürecinde öğretmen öğrenciye yol gösterirken bilgiyi onun 


\section{0-6 Yaş Arasındaki Çocuklara Sözcük Öğretimi ile ilgili Çalışmaların İncelenmesi}

keşfetmesini sağlar. Türkçe derslerinde kelime öğretiminde teorik bilgilerin yanı sıra uygulamanın esas olduğu çalışmalar da bulunmaktadır. 0-6 yaş arasındaki çocuklara sözcük öğretimiyle ilgili yapılan uygulama odaklı çalışmaların çalışma konuları genellikle sosyoekonomik durumunun, ailenin eğitim seviyesinin, anaokuluna devam edip etmeme durumunun, okul öncesi eğitimde kullanılan teknik ve yöntemlerin çocuğun dil düzeyine etki edip etmediği yönündedir.

Okul öncesi dönem, çocuğun bedensel ve zihinsel gelişiminin en hızlı olduğu yıllar olarak kabul edilmektedir. Okul öncesi dönemdeki etki ve yönlendirmeler çocuğun gelişimini sağladığı gibi toplumların gelişmesine de katkıda bulunmaktadır. Okul öncesi dönemin zengin uyarıcıları olarak kabul edilen anne-baba ve öğretmenler, onların kullandıkları eğitim teknikleri, kullanılan materyaller ve çocuk kitapları çocukların dili öğrenmelerinde ve etkin olarak kullanmalarında vazgeçilmez unsurlar olarak kabul edilmektedir. Çocuğa güzel bir dil ve anlatım yeteneği kazandıran bu unsurlar, diğer gelişim alanlarının, özellikle de zihin gelişiminin desteğiyle daha etkili olmaktadır. Çocukların yeni yeni sözcükler öğrenmesi alıcı dil düzeyini, sözcük dağarcığını zenginleştirerek, ifadelerinin de gelişmesini sağlamaktadır.

Koçak ve Aydoğan (2003) okul öncesi çocukların dil gelişimine etki eden faktörleri incelemişlerdir. Araştırma sonucunda cinsiyetin, çocukların devam ettikleri okul öncesi eğitim kurumunun resmi oluşunun ve devam süresinin uzunluğunun, anne-baba öğrenim düzeyinin, çocukların sahip oldukları kardeş sayısının çocukların dil gelişimi üzerinde etkili olduğu saptanmıştır.

Bal (1988) anaokuluna giden ve gitmeyen 4-6 yaşlar arasındaki çocukların kullandıkları ifadeleri sözdizimi yönünden incelemiştir. Araştırma sonucunda tek, iki, üç, dört, beş ve altı sözcüklü ifadelerin kullanım sıklığı yönünden anaokuluna giden ve gitmeyen 50 - 59 ay erkek grupları arasında, ayrıca anaokuluna giden ve gitmeyen 60 - 71 ay erkek grupları arasındaki farklılık istatistiksel olarak anlamlı bulunmuştur. Anaokuluna giden ve gitmeyen tüm gruplar, kullanım yüzdesi yönünden iki, üç, dört sözcüklü ifadeleri yüksek oranda, tek sözcüklü ifadeler ile 6 ve daha fazla sözcüklü ifadeleri ise daha düşük oranda kullanmışlardır.

Öztürk (1995) okulöncesi eğitim kurumlarına giden ve gitmeyen ilkokul birinci sınıf öğrencilerinin alıcı ve ifade edici dil düzeylerini saptamıştır. Araştırma sonucuna göre okul öncesi eğitim kurumlarına giden öğrencilerin alıcı dil düzeyleri, ifade edici dil düzeyleri ("resimleri isimlendirme" ve "resimleri işlevlerine göre tanımlama" düzeyleri), gitmeyenlerden yüksek bulunmuştur.

Seçilmiş (1996)'te ise bu çalışmalarda çıkan sonuçların aksine bir sonuç elde edilmiştir. Yapılan bu araştırma sonucunda, 37-72 aylar arasındaki özel ve kurum anaokullarına devam eden çocukların başarı düzeyleri arasında anlamlı farklar bulunmamıştır. 
Dil gelişim dönemleri belli yaş sınırları içinde her çocuğa göre değişmektedir. Bu nedenle çocukların dil gelişimleri zaman yönünden birbirinden farklılıklar göstermektedir. Bunun nedenleri üzerine yapılan araştırmalarda ırk özellikleri, cinsiyet, sosyoekonomik durum, anne-baba eğitimi, kardeş sayısı gibi birçok etken incelenmiş ve birbirleriyle çelişen sonuçlar elde edilmiştir.

Erdemir (2001)'de 12-30 aylar arasındaki Türk çocuklarında Türkçeyi öğrenirken dildeki yapıları ve sözcük türlerini anlama yönünden ne gibi aşamalar geçirdiklerini saptanmış ve bu aşamaların kazanılmasında cinsiyet ve annenin eğitim durumunun etkilerini belirlenmiştir. Araştırma sonuçların göre Alıcı Dil Kontrol Listesi'nin çocukların alıcı dil gelişimlerini izlemede uygun bir araç olduğu belirlenmiştir. Çocukların, sözcükleri ve bazı dil yapılarını anlama ve kullanmada yaşa göre değişiklikler önemli bulunmuştur. Cinsiyet değişkeni ile ilgili bulgularda kız ve erkek çocuklar arasında alıcı dil gelişimi yönünden genel olarak bir farklılık bulunmamıştır. Annelerin eğitim düzeyinin çocukların dil gelişimlerinin bazı boyutlarını etkilediği saptanmıştır.

Güler (2004) orta sosyoekonomik düzeydeki ailelerin anaokuluna devam eden 48-72 aylar arasındaki çocuklarının Türkçedeki dil bilgisi yapılarını ve sözcükleri anlamada geçirdikleri aşamaların, cinsiyet, yaş, anne ve baba eğitim düzeyi, çocuğun doğum sırası ve kardeş sayısı değişkenlerine göre nasıl bir gelişim gösterdiği belirlemiştir. Araştırma sonucunda çocukların dil bilgisi yapılarını ve sözcükleri anlama düzeylerinin yaşla birlikte gelişim gösterdiği görülmüştür.

Acarlar vd. (2002) Türk çocuklarının farklı özellikteki üstdil işlemlerindeki performansları incelemiştir. Araştırmanın sonuçları üstdil işlemlerindeki başarının yaşla arttığını ve işlemin özelliklerine göre farklıık gösterdiğini ortaya koymuştur.

Gürocak (2007) anasınıfına devam eden 60-72 ay çocukların dil gelişimi ve ince motor gelişimi açısından değerlendirmesini yapmıştır. Yapılan çalışma sonucunda; dil gelişimi ve motor gelişimin yas ve cinsiyet değişkenine göre farklılık göstermediği anlaşılmıştır.

Erdoğan, Şimşek vd. (2005) alt sosyoekonomik bölgelerde ana sınıfına devam eden 5-6 yaş grubundaki çocukların dil gelişim düzeylerine cinsiyet, ana sınıfına devam süresi, anne eğitim düzeyi, anne mesleği, kardeş sayısı ve doğum sırasının etkisini araştırmıştır. Araştırma bulguları ana sınıfına devam eden 5-6 yaş grubundaki çocukların cinsiyetin, anne eğitiminin, anne mesleğinin, kardeş sayısının ve doğum sırasının etkili olmadığını ortaya koymaktadır.

Okul öncesi eğitimin amaçlarından özellikle dil gelişimi ile ilgili olanlar doğrudan ya da dolaylı olarak öne çıkmakta ve birçok alanı çok boyutlu olarak etkilemektedir. Konunun önemiyle ilgili olarak, MEB Okul Öncesi Eğitim Programı́nda; okul öncesi eğitim kurumlarındaki eğitim etkinlikleri içinde Türkçe etkinlikleri de yer almakta ve Türkçe etkinlikleri sırasında çocukların Türkçeyi doğru ve güzel konuşmalarının sağlanması ile sözcük dağarcıklarının geliştirilmesi üzerinde önemle durulmasının 


\section{0-6 Yaş Arasındaki Çocuklara Sözcük Öğretimi ile ilgili Çalışmaların İncelenmesi}

gerektiği vurgulanmaktadır. (MEB, 2013: 43, 54). Bu doğrultuda incelenen çalışmaların okul öncesi eğitimde kullanılan bazı yöntem ve tekniklerin öğrencilerin sözcük öğrenmelerine etkililiği şeklinde olduğu görülmektedir.

Çelik (2005) çalışmasında eğitici oyuncakların okul öncesi eğitim kurumuna devam etmekte olan 6 yaş grubu çocukların, zaman kavramını öğrenme düzeylerine etkisini araştırmıştır. Araştırma sonucunda sonucu eğitici oyuncak zaman kavramı eğitil programının okul öncesi eğitime devam etmekte olan 6 yaş grubu öğrencilerinin zaman kavran öğrenme düzeylerini arttırmada etkili olduğunu ortaya çıkmıştır.

Denk (2000) anaokuluna devam eden 6 yaş grubundaki çocukların alıcı dil gelişim düzeylerine müzik eğitiminin etkisi incelemiştir. Araştırma sonucunda destekleyici olarak uygulanan müzik eğitim programlarının çocukların alıcı dil gelişimine olumlu etkileri olduğu bulunmuştur.

Dereobalıoğlu (1994) anaokuluna devam eden $48 \pm 2$ aylık çocuklara normal eğitimlerine ek olarak verilen destekleyici algı eğitiminin çocukların dil gelişimleri üzerindeki etkisinin incelemiştir. Araştırma sonucunda normal eğitime ek olarak verilen destekleyici algı eğitiminin dil gelişimi üzerinde olumlu etkileri olduğu bulunmuştur.

Yayla (2003) dil eğitim programının alt sosyoekonomik düzeydeki ailelerden gelen 60- 72 aylar arasındaki çocukların dil gelişimine etkisinin incelemiştir. Araştırma sonucuna göre erken çocukluk yıllarında çocukların alıcı ve ifade edici dil düzeylerini, sözcük dağarcığının gelişimini destekleyecek dil eğitim programlan geliştirilmeli ve yaygınlaştırımalıdır.

Yurtsever (2002)'de okul öncesi eğitim kurumlarına devam eden beş-altı yaş grubu çocukların kelime dağarcığı gelişimini desteklemek amacıyla sistemli olarak hazırlanmış ana dil eğitim programının, çocukların kelime dağarcığı gelişimindeki etkililiğini ortaya koymak amacı ile planlanmıştır. Araştırma sonucunda örneklemde yer alan 5-6 yaş çocukların kelime dağarcığı gelişimine, uygulanan ana dil eğitim programının olumlu etkisi olduğu görülmüştür.

Gönen vd. (2010) öğrencilerden ayrı olarak öğretmenlerin dil etkinliklerini uygulama biçimlerini belirlemişlerdir. Araştırma sonuçlarına göre, öğretmenlerin çoğunluğu dil etkinliklerine günlük programlarında yarım saate kadar yer ayırmaktadır. Yine öğretmenlerin çoğunluğu bu etkinliklere çocukların dil gelişimini desteklemede etkili olduğunu düşündüğü için yer vermektedir. Öğretmenler dil etkinlikleri öncesinde genellikle öğrencilerle sohbet etmeyi tercih etmektedir. Öğretmenler dil etkinlikleri sonrasında 'olay sıralaması ve kahramanlarının özellikleri ile ilgili sorular sorma' etkinliğini sıklıkla yapmaktadır. Öğretmenler dil etkinliklerinde araç olarak çoğunlukla kitaplar ve kuklaları kullanmaktadırlar. Data show ve slaytlar ise en az kullanılan araçlardır. 
Görüldüğü gibi çalışmalarda çocukların kelime hazinelerini betimlemeye veya arttırmaya yönelik çalışmalar ağırlık kazanmıştır. Bu çalışmalara ek olarak öğrencilere hangi kelimelerin edindirilmesi konusu da sözcük öğretiminde önemli bir unsurdur. Keklik (2011) çalışmasında güncel Türkçede birleşim gücü yüksek olan ilk bin kelime belirlemiş̧ir. Araştırmaya göre ilk bin kelimeyi, sıklığı yedi ve üzeri kelime türeten madde başı kelimeler oluşturmaktadır. Sıklığı yedi ve üzeri olan bu kelimelerin oluşturduğu birleşik kelime sayısı 17985'tir. Bu kelimeler başka araştırmalarla karşılaştırıldığında sık kullanılan kelimeler ve 0-11 yaş arası çocuğun seviyesine uygun kelimeler olduğu belirlenmiştir. Keklik (2011)'in bir başka çalışmasında ise Türkçede en sık kullanılan 3000 kelimeyi belirlenerek bu kelime listesi içerisinden 120 tane karşıt anlamlı kelimenin altı, sekiz, on ve on bir yaş grubu öğrencileri tarafından bilinme seviyesini ortaya çıkarmıştır. Araştırma sonucunda 0-11 yaş grubu için belirlenen 3000 kelime; 0-6 yaş için 1200, 7-11 yaş için 1800 şeklinde ayrılarak üst kavramlarına göre listelenmiştir. Bütün gruplarda en çok bilinen karşıt anlamlı kelimeler, aşağı/yukarı, boş/dolu ve hızı/yavaş iken en az bilinen kelimeler ise zalim/masum, mazlum, alçak gönüllü/gururlu ve doğrudan/dolaylı kelimeleridir.

Çalışmalara bakıldığında uygulamanın esas olduğu 18 çalışmadan elde edilen bulgular şu şekildedir:

- Ailenin sosyoekonomik düzeyi, anne ve babanın öğrenim düzeyi, kardeş sayısı, çocuğun okulöncesi eğitim alması çocuğun dil gelişimine etki etmektedir.

- Çocukların dil gelişimi cinsiyete göre bir farklılık göstermemektedir.

- Araştırmalarda Türkçede en sık kullanılan kelimeler betimlenerek 0-6 yaş arası çocukların öğrenmesi gereken kelimeler belirlenmiştir.

- Okulöncesi eğitimde verilen ek eğitim programları (müzik eğitimi, algı eğitimi vb. ) çocukların dil gelişimlerine olumlu etkide bulunmaktadır

\section{Teorik Bilgi Veren Çalışmalar}

Teorik bilgiler bir araştırmayı uygulama aşamasına geçirmek için oldukça önemlidir. 0-6 yaş çocuklara sözcük öğretimiyle ilgili yapılan teorik çalışmaların çoğunluğunda dil edinimi, çocukların dil edinim süreçleri, dil edinimindeki kritik dönemler hakkında bilgi verilmiş, sözcük öğretiminde kullanılabilecek etkinlikler sunulmuştur.

Demir (2011) öncelikle çocukların dil gelişimi hakkında bilgi verilmeye çalışmış, dil gelişiminin büyük ölçüde tamamlandığı 0-6 yaş grubundaki çocuklara verilen eğitimin önemi hakkında örneklerle açıklamalar yapmış, çeşitli araştırmacıların bulgularından yararlanılarak çocukların dil gelişimlerini olumsuz yönde etkileyen durumlar ve bu konuda dikkat edilmesi gerekenler hakkında bilgi vermiştir.

Temel (1999) 0-6 yaş aralığındaki çocukların dil gelişim evrelerinden söz etmiştir. 
0-6 Yaş Arasındaki Çocuklara Sözcük Öğretimi ile ilgili Çalışmaların İncelenmesi

Demirezen (2003) yabancı dil ve anadil öğreniminde kritik dönemlerin doğruluğunu, işlerliğini, dil öğretimiyle olan ilişkilerini irdelemiştir.

Çavuşoğlu (2006) anadil ediniminin önemine değinmiş, anadil bilincinin kazandırılması hakkında bilgi vermiştir.

İlhan (2005) çocukların anadil edinmelerinin öneminden bahsedilmiş ve bu edinim sürecinde ailenin büyük bir önemi olduğundan söz etmiş̧ir.

Dağabakan ve Dağabakan (2007) birçok dil uzmanının dil hakkındaki görüşlerinden yola çıkarak dilin ayrıntılı bir tanımı yapılmaya ve aynı zamanda dilin gelişimini açıklayan ünlü teoriler ele alarak çocukta erken yaşlarda dil gelişimi hakkında okuyucuya bir ışık tutmaya çalışmışlardır.

Funda Acarlar (2002) dilin değerlendirilmesinde önemli bir yaklaşım olarak betimleyici yaklaşım ve bazı ölçüt-bağımlı işlemleri incelemiştir.

Milli Eğitim Bakanlığının (2013) hazırlamış olduğu çalışmada çocukların dil gelişim özellikleri hakkında bilgiler verilmiş ve dil gelişimiyle ilgili örnek etkinlik ve araç gereçler sunulmuştur.

Dönmez vd. (2000) çocuğun doğal bir süreç içerisinde oluşan dil gelişimini eğitim yoluyla desteklemek amacıyla çalışmalarında çeşitli etkinlikler sunmuşlardır. Çalışmada sunulan etkinlikler, çocuğun anadili edinimine ve dil gelişimine yardımcı olacak türdendir. Etkinlikler evde, dışarıda ve sınıfta rahatlıkla kullanılabilecek nitelikte olduğu için çalışma, başta anne ve babalar olmak üzere eğitimcilerin, alanla ilgili uzmanların ve öğrencilerin yararlanabilecekleri bir kaynaktır.

\section{Sonuç ve Öneriler}

Yapılan tarama çalışması sonucunda 0-6 yaş arası çocuklara sözcük öğretimi ile ilgili toplam 41 çalışma tespit edilmiştir. Sözcük öğretiminde esas alınan veriler baz alınarak çalışmalar üç başlık altında sınıflandırımıştır. Araştırma sonunda kelime hazinesine yönelik 12 çalışma; uygulamanın esas olduğu 19 çalışma; teorik bilgi veren 9 çalışma tespit edilmiştir. Çalışmalar genel olarak incelendiğinde kelime hazinesine yönelik çalışmaların genel olarak 4-6 yaşları arasındaki çocuklar üzerinde yapıldığı 4 yaşın altındaki çocuklara yönelik az çalışmanın olduğu görülmektedir. Bu çalışmaların genelinde okul öncesi eğitimi alan öğrencilerin sözcük hazinesinin ölçülmeye çalışılmıştır. Okul öncesi eğitim almayan ve 4 yaşın altındaki çocuklara yönelik çalışmaların yapılması çocukların dil edinim aşamalarını net olarak görülmesine fayda sağlayacaktır.

Milli Eğitim Bakanlığı Okulöncesi Eğitim Programı (2013) kazanımlarında yer alan “Dinlediklerinin/izlediklerinin anlamını kavrar. Dinlediklerini/izlediklerini çeşitli yollarla ifade eder. Görsel materyalleri okur. " gibi kazanımlar göz önünde bulundurulduğunda çalışmalarda dinleme, izleme gibi becerilerin üzerinde durulmadığı açık bir şekilde görülmektedir. 0-6 yaş arası çocuklara yönelik çocuklara 
sözcük öğretimi kapsamında yapılan çalışmaların bu becerilere yönelmesi bu kazanımlara dair materyallerin gelişmesinde ve bu kazanımların gelişiminde yararlı olacaktır.

\section{Kaynaklar}

Acarlar, F. (2002). Çocuklarda dilin değerlendirilmesi: Betimleyici yaklaşım. Ankara Üniversitesi Eğitim Bilimleri Fakültesi Dergisi, 35(1), 121-128.

Acarlar, F. , Ege, P. ve Turan, F. (2002). Türk çocuklarında üst dil becerilerinin gelişimi ve okuma ile ilişkisi. Türk Psikoloji Dergisi, 17(50), 63-73.

Acarlar, F. . (1991). 2,5-4 Yaşlar Arasındaki Türk Çocuklarının Dil Yapılarııın İncelenmesi: Ankara. Hacettepe Üniversitesi Sağlık Bilimleri Enstitüsü Yüksek Lisans Tezi.

Aktürk, B. (2012). Understanding the Gestural, Lexical and Grammatical Development of Turkish-Speaking Infants and Toddlers: Validity Study of the Turkish Communicative Development Inventory (TIGE): Ankara, Hacettepe Üniversitesi Sağlık Bilimleri Enstitüsü, Yayımlanmamış Yüksek lisans Tezi.

Artar, M. (1988). Ankara'da Yaşayan 9-26 Aylık Çocuklarda Aile Bilgisine Dayalı Dil Normlarının Saptanması: Ankara,Ankara Üniversitesi Sosyal Bilimler Enstitüsü Yayımlanmamış Doktora Tezi.

Aydoğan, Y ve Koçak, N. (2003). Okul Öncesi Çocukların Dil Gelişimlerine Etki Eden Faktörlerin İncelenmesi. Milli Eğitim Dergisi, 159.

BAL, S. (1988). Kütahya III Merkezinde Anaokuluna Giden ve Gitmeyen 4-6 Yaşlar Arasındaki Çocukların Kullandıkları İadelerin Sözdizimi Yönünden incelenmesi: Ankara, Hacettepe Üniversitesi Sağlık Bilimleri Enstitüsü Yayımlanmamış Doktora Tezi.

Çavuşoğlu A. (2006). Ana Dili, Edinimi, Önemi Ve Geliştirilmesi. Fırat Üniversitesi Illahiyat Fakültesi Dergisi, s. 1 , ss. $37-46$.

Çelik, C. (2005). Oyun Materyallerinin Okulöncesi Eğitim Çağındaki Çocukların Kavram Gelişimi Üzerindeki Etkisinin İncelenmesi. Konya: Selçuk Üniversitesi Sosyal Bilimler Enstitüsü Yüksek Lisans Tezi.

Dağabakan, Ö. Ve Dağabakan F. (2007). Dil ve Çocukta Dil Gelişim Kuramları, İnternetten 20. 05. 2014'te http://ooegm. meb. gov.tr/dokuman/cocuklarda_dil_gelisimi. pdf adresinden alınmıştır.

Demir S. (2011). Okul Öncesi Dönemde Dil Gelişimi ve Sorunları. Gazi Üniversitesi Türkçe Araştırmaları Akademik Öğrenci Dergisi, 1, 39-49.

Demirezen, M. (2003). Yabanci Dil ve Anadil Öğreniminde Kritik Dönemler. TÖMER Dil Dergisi, 118, 5-15. 
0-6 Yaş Arasındaki Çocuklara Sözcük Öğretimi ile ilgili Çalışmaların İncelenmesi

Denk, D. (2000). Anaokuluna Devam Eden 6 Yaş Grubundaki Çocukların Alıcı Dil Gelişim Düzeylerine Müzik Eğitiminin Etkisinin İncelenmesi. Ankara: Hacettepe Üniversitesi Sağlık Bilimleri Enstitüsü Yüksek Lisans Tezi.

Dereli, E. (2003). Okul Öncesi Eğitime Devam Eden 4-6 Yaş Arasındaki Çocukların Ifade Edici Dil Düzeylerinin İncelenmesi (Konya ili Örneği). Ankara: Selçuk Üniversitesi Sosyal Bilimler Enstitüsü Yüksek Lisans Tezi.

Dereobalı, N. (1994). Anaokuluna Devam Eden 48 Aylık Çocukların Algısal Becerilerinin Geliştirilmesine Yönelik Hazırlanan Programların Dil Gelişimi Yönünden İncelenmesi. Ankara: Hacettepe Üniversitesi Sağlık Bilimleri Enstitüsü Yüksek Lisans Tezi.

Dönmez Baykoç, N. , Abidoğlu,, Ü, Dinçer, Ç. , Erdemir, N. , Gümüşçü Ş. (2000) Dil Gelişim Etkinlikleri, Ya-pa Yayıncılık, İstanbul.

Ekmekci, Ö. (1979). Acquisition of Turkish: A Longitudinal Study on the Early Language Development of a Turkish Child. Austin: Teksas Üniversitesi Yayımlanmamış Doktora Tezi.

Erdemir, N. (2001). 12-30 Aylar Arasındaki Türk Çocuklarının Dil Yapılarının Anlamsal Yönden İncelenmesi. Ankara: Hacettepe Üniversitesi Sağlık Bilimler Enstitüsü Yayımlanmamış Doktora Tezi.

Erdoğan, S. , Şimşek B. H. , Erdoğan A. (2005). Ankara'nın Alt Sosyoekonomik Bölgelerinde Ana Sınıfına Devam Eden 5-6 Yaş Çocuklarının Dil Gelişim Düzeylerine Bazı Faktörlerin Etkisinin İncelenmesi. Çukurova Üniversitesi Sosyal Bilimler Dergisi, 1, 231-246.

Erkan, P. (1990). Sosyoekonomik ve Eğitim Düzeyleri Farklı Olan Ailelerin 48-60 Aylar Arasındaki Çocukların Dil Yapılarının İncelenmesi. Ankara: Hacettepe Üniversitesi Sağlık Bilimleri Enstitüsü, Y. Lisans Tezi, Tez nu:11363.

Fromkin, V. ve D. Rodman. 1978. An Introduction to Language. New York: Holt, Rinehart and Winston.

Gökmen, S. , (2007). 4;0-6;0 Yaş (48-72 Aylar) Arasındaki Çocukların Ad-Eylem Kullanımları. Dil Dergisi, 137, 18-29.

Gönen, M. , Ünüvar, P. , Bıçakçı M. , Koçyiğit S. , Yazıcı, Z. , Orçan M. , Aslan D. , Güven G. Ve Özyürek A. (2010). Okul Öncesi Eğitim Öğretmenlerinin Dil Etkinliklerini Uygulama Biçimlerinin İncelenmesi. Mehmet Akif Ersoy University Journal of Education Faculty, 19, 23-40.

Güler, T. (2004). 48-72 Aylar Arasındaki Türk Çocukların Alıcı Dil Yapılarının İncelenmesi. Ankara: Hacettepe Üniversitesi Sağlık Bilimleri Enstitüsü, Doktora Tezi.

Güleryüz, F. (1990). 48-60 Aylar Arasındaki Türk Çocuklarının Dil Yapılarının İncelenmesi. Ankara:Hacettepe Üniversitesi Sağıık Bilimleri Enstitüsü Bilim Uzmanlığı Tezi. 
Gürocak Ünal, S. (2007). Anasınıfına Devam Eden 60-72 Ay Çocukların Dil Gelişimi ve İnce Motor Gelişimi Açısından Değerlendirilmesi, Bolu: Abant İzzet Baysal Üniversitesi, Sosyal Bilimler Enstitüsü Yüksek Lisans Tezi.

İlhan, N. (2005) Çocukların Dil Edinimi, Dil Gelişimi ve Dile Katkıları. Manas Üniversitesi Sosyal Bilimler Dergisi, 13, 155-160.

Karasar, N. (2010). Bilimsel Araştırma Yöntemi. Ankara: Nobel Yayınevi.

Keklik, S. (2009). On Bir Yaşına Kadar Çocukta Dil Edinimi. İstanbul: Marmara Üniversitesi Eğitim Bilimleri Enstitüsü Yayınlanmamış Doktora Tezi.

Keklik. S. (2011). Türkçede On Bir Yaşına Kadar Çocuklara Öğretilmesi Gereken, Birleşim Gücü Yüksek ilk Bin Kelime. ODÜ Sosyal Bilimler Enstitüsü Sosyal Bilimler Araştırmaları Dergisi, 4,80-95.

MEB (2013). Okulöncesi Eğitim Programı ve Kılavuzu, Ankara: Devlet Kitapları Müdürlüğü Basım Evi.

Öztürk, H. (1995). Okulöncesi Eğitim Kurumlarına Giden ve Gitmeyen Illkokul Birinci Sınıf Öğrencilerinin Alıcı ve Ifade Edici Dil Düzeyleri, Ankara: Gazi Üniversitesi Sosyal Bilimler Enstitüsü Yüksek Lisans Tezi.

Savaş, M. ve Turan, M. (2011). Okulöncesi Altı Yaş Grubu Öğrencilerin Sahip Oldukları Kelime Servetinin Incelenmesi. New World Science Academy (NWWSA), 6.

Seçilmiş, S. (1996). Anaokuluna Giden ve Gitmeyen Erken Çocukluk Dönemindeki Çocukların Dil Gelişimi ile ilgili Becerilerinin İncelenmesi. Ankara: Hacettepe Üniversitesi Sağlık Bilimleri Enstitüsü Yayımlanmamış Yüksek Lisans Tezi.

Temel, F. (1999). 0-6 Yaş Çocuklarında Dilin Kazanılması. Türk Dili Dil ve Edebiyat Dergisi: Ankara. 572, 715721.

Tura Sansa, S, (1983). Dilbilimin Dil Öğretimindeki Yeri. Türk Dili, Dil Öğretimi Özel Sayısı: Ankara Türk Dil Kurumu Yayınları. 379- 380. sy. , 8-17. ss.

Yayla, ş. (2003). Alt Sosyo-ekonomik Düzeydeki Ailelerden Gelen 60-72 Aylar Arasındaki Çocuklara Uygulanan Dil Eğitim Programının Çocukların Dil Gelişimine Etkisinin İncelenmesi. Ankara: Gazi Üniversitesi Eğitim Bilimleri Enstitüsü Yayımlanmamış Yüksek Lisans Tezi.

Yıldırım Doğru S. S, Bek H. , Konuk Er R, Demiray P. (2010). Engelli ve Normal Gelişim Gösteren Okul Öncesi Çocukların Sözcük Dağarcığı Düzeylerinin Belirlenmesi, Tübav Bilim Dergisi, 4,335-341.

Yurtsever, M. (2002). Beş-Altı Yaş Çocukların Kelime Dağarcığı Gelişimine Ana Dil Eğitim Programının Etkisi. İstanbul: Marmara Üniversitesi Eğitim Bilimleri Enstitüsü Yayımlanmamış Yüksek Lisans Tezi. 
0-6 Yaş Arasındaki Çocuklara Sözcük Öğretimi ile ilgili Çalışmaların İncelenmesi

Yüksel, E. (2003). Eskişehir'de yaşayan 30-47 Aylar Arasındaki Çocukların Alıcı Dil Becerilerinin İncelenmesi. Ankara: Hacettepe Üniversitesi Sağlık Bilimleri Enstitüsü Yayımlanmamış Yüksek Lisans Tezi.

Zembat, R. ve Yurtsever, M., (2002). “Beş-altı Yaş Çocuklarının Kelime Dağarcı̆̆ı Gelişimine Ana Dil Eğitim Programının Etkisi”. Erken Çocukluk Gelişimi Eğitimi Sempozyum Bildiriler. KÖK 